\title{
Transport and degradation of perchlorate in deep vadose zone: implications from direct observations during bioremediation treatment
}

\author{
Ofer Dahan, Idan Katz, Lior Avishai, and Zeev Ronen \\ Zuckerberg Institute for Water Research (ZIWR), The Blaustein Institutes for Desert Research, \\ Ben-Gurion University of the Negev, Sede Boqer Campus, 8499000, Israel
}

Correspondence to: Ofer Dahan (odahan@bgu.ac.il)

Received: 15 December 2016 - Discussion started: 23 January 2017

Revised: 11 June 2017 - Accepted: 14 June 2017 - Published: 8 August 2017

\begin{abstract}
An in situ bioremediation experiment of a deep vadose zone $(\sim 40 \mathrm{~m})$ contaminated with a high concentration of perchlorate $\left(>25000 \mathrm{mg} \mathrm{L}^{-1}\right)$ was conducted through a full-scale field operation. Favourable environmental conditions for microbiological reduction of perchlorate were sought by infiltrating an electron donor-enriched water solution using drip irrigation underlying an airtight sealing liner. A vadose zone monitoring system (VMS) was used for real-time tracking of the percolation process, the penetration depth of dissolved organic carbon (DOC), and the variation in perchlorate concentration across the entire soil depth. The experimental conditions for each infiltration event were adjusted according to insight gained from data obtained by the VMS in previous stages. Continuous monitoring of the vadose zone indicated that in the top $13 \mathrm{~m}$ of the cross section, perchlorate concentration is dramatically reduced from thousands of milligrams per litre to near-detection limits with a concurrent increase in chloride concentration. Nevertheless, in the deeper parts of the vadose zone $(<17 \mathrm{~m})$, perchlorate concentration increased, suggesting its mobilization down through the cross section. Breakthrough of DOC and bromide at different depths across the unsaturated zone showed limited migration capacity of biologically consumable carbon and energy sources due to their enhanced biodegradation in the upper soil layers. Nevertheless, the increased DOC concentration with concurrent reduction in perchlorate and increase in the chloride-to-perchlorate ratio in the top $13 \mathrm{~m}$ indicate partial degradation of perchlorate in this zone. There was no evidence of improved degradation conditions in the deeper parts where the initial concentrations of perchlorate were significantly higher.
\end{abstract}

\section{Introduction}

In situ bioremediation of a contaminated unsaturated zone (also termed vadose zone) depends mainly on the ability to control the hydrological, physical and chemical conditions in the subsurface (Bombach et al., 2010; EPA, 2015; Höhener and Ponsin, 2014). Chemical and hydrological manipulations are primarily aimed at enhancing the activity of specific indigenous degrading bacteria. The optimal conditions for specific contaminants' degradation are usually determined in microcosm experiments, where the preferred electron donor and acceptor for degradation can be controlled and examined (Gal et al., 2008; Megharaj et al., 2011; Sagi-Ben Moshe et al., 2012). The optimal degradation conditions, evaluated through laboratory experiments, usually form the basis for selecting a strategy for in situ remediation in field-scale operations. Nevertheless, implementation of desired biodegradation conditions in the deep vadose zone through full-scale field setups requires control of the vadose zone hydrogeochemical conditions. This is often achieved through either infiltration of water enriched with electron donors or nutrients (Battey et al., 2007; EPA, 2004; Frankel and Owsianiak, 2005 ), or injection of a gaseous mixture capable of promoting optimal biogeochemical conditions for microbial pollutant degradation (Evans et al., 2011; Evans and Trute, 2006). Due to the complex nature of flow and transport processes in the unsaturated zone, application of water with specific chemical conditions near land surface does not necessarily result in promoting the desired geochemical and hydraulic conditions in deeper parts of the vadose zone (Allaire et al., 2009; Flury and Wai, 2003; Jarvis, 2007; Rimon et al., 
2011a). Therefore, in the vadose zone, and particularly in its deeper parts, a proper understanding of the transport process is key to the success of in situ remediation operations (Baram et al., 2012a; Dahan et al., 2009; Kurtzman et al., 2016; Rimon et al., 2011a).

Assessment of water percolation and solute transport in the vadose zone is considered a major challenge in hydrological sciences. It is often characterized by unstable flow that is highly sensitive to hydraulic, chemical and microbial conditions (Bautersa et al., 2000; Dahan et al., 2009; DiCarlo, 2007; Germann and al Hagrey, 2008; Hallett et al., 2013; Rimon et al., 2011a; Sher et al., 2012; Stumpp et al., 2009). Moreover, the chemical composition of the percolating water (e.g. dissolved organic carbon (DOC), oxygen and nutrients) is subjected to frequent changes due to natural hydroclimatic and biological cycles (Stumpp et al., 2009, 2012). Accordingly, contaminant attenuation in the vadose zone is dependent on the complex hydrological, chemical and biological states of the sediment. Continuous measurements of the hydrological and chemical properties of the unsaturated zone may be achieved with a vadose zone monitoring system (VMS) (Dahan et al., 2009). The VMS provides highresolution measurements of variation in sediment water content (Dahan et al., 2008; Rimon et al., 2007) and evolution of the pore water's chemical composition across the unsaturated profile (Rimon et al., 2011a; Dahan et al., 2014; Turkeltaub et al., 2014, 2016).

Perchlorate is an environmental pollutant that is often associated with the explosives manufacturing industry (Roote, 2001; Urbansky, 2002; Trumpolt et al., 2005). It is mostly produced, and consequently released to the environment as ammonium perchlorate. Its high solubility $\left(220 \mathrm{~g} \mathrm{~L}^{-1}\right)$ and stability in aerobic environments makes it very mobile and persistent in the subsurface (Motzer, 2001; Urbansky and Brown, 2003). Microbial reduction of perchlorate to harmless chloride and oxygen in the unsaturated zone requires elevated water content, negative redox potential, available electron donors and the presence of suitable indigenous bacteria (Coates and Achenbach, 2004). In the vadose zone, natural attenuation and biodegradation of perchlorate are considered very limited (Gal et al., 2009). Nevertheless, studies have shown that perchlorate can be metabolized in unsaturated soil whenever reducing conditions $(<110 \mathrm{mV}$ ) (Attaway and Smith, 1993; Shrout and Parkin, 2006) are achieved and an available electron donor is introduced (Tipton et al., 2003; Frankel and Owsianiak, 2005; Nozawa-Inoue et al., 2005; Evans and Trute, 2006; Cai et al., 2010).

Here, the efficiency of a remediation operation of a perchlorate-contaminated vadose zone was assessed using a VMS, which provided continuous information on the chemical composition of the vadose zone pore water. Promotion of perchlorate-degrading conditions in the vadose zone was based on infiltration of water enriched with ethanol (as a source of electron donor) from land surface. Real-time information on the depth of the enriched water's propagation, along with variations in the concentrations of perchlorate, chloride and bromide (applied as a tracer), was used to assess transport and degradation of perchlorate across the unsaturated profile. Water- and ethanol-application strategies were adjusted in each flow phase to obtain real-time feedback on the chemical and hydrological state of the vadose zone.

\section{Study site}

The study area is located in the central part of the Israeli coastal plain, east of the city of Ramat Hasharon. The site is a former unlined earthen pond that was used to store industrial wastewater for several decades. A hydrogeological survey conducted in the study area revealed substantial perchlorate contamination in the vadose zone and groundwater under the pond area (Gal et al., 2008, 2009). It was concluded that percolation of untreated wastewater from the ponds had crossed the $40 \mathrm{~m}$ thick vadose zone and created a large perchlorate pollution plume in the underlying phreatic aquifer with concentrations exceeding $1000 \mathrm{mg} \mathrm{L}^{-1}$. In the vadose zone, however, the investigation revealed extreme perchlorate pollution, reaching concentrations exceeding $2000 \mathrm{mg} \mathrm{kg}^{-1}$ dry soil (equivalent to $\sim 25000 \mathrm{mg} \mathrm{L}^{-1}$ in the sediment pore water), along with high total salinity and chloride concentration exceeding $25000 \mathrm{mg} \mathrm{L}^{-1}$. Because this area is under consideration for future urban development, remediation of both the vadose zone and groundwater there is of major concern.

The stratigraphy of the area is characterized by Neogene and Pleistocene sediments, mainly of sands and sandstones with interbedding of clay lenses (Gvirtzmen, 2002). The vadose zone lithological profile at the site was assessed again through a borehole that was drilled at the pilot site in 2012 (Table 1, Fig. 1). Most of the profile is composed of yellow and red sand layers with low clay content $(<5 \%)$, with interbeds of brown sand containing variable clay content of up to $11 \%$. A single $\sim 1 \mathrm{~m}$ thick clay layer ( $27.5 \%$ clay content) was observed at a depth of $13.3 \mathrm{~m}$. To improve infiltration capacity in deep sections of the vadose zone during the remediation experiment, a shallow clay layer with low permeability, known as nazaz (Singer, 2007), was removed from a depth of $2.5-3 \mathrm{~m}$ by excavation. The excavated area, $10 \times 30 \mathrm{~m}$, which was primarily assigned for the pilot infiltration experiment, was backfilled with the sandy loam from the excavated site after removal of the $0.5 \mathrm{~m}$ thick nazaz layer. This layer is therefore presented in the profile as disturbed soil.

The climate in the area is characterized as subtropical Mediterranean with a hot and dry summer from May to October and a colder wet winter from November to April. The average air temperature on summer and winter days is 30 and $17^{\circ} \mathrm{C}$, respectively. The average annual precipitation is $530 \mathrm{~mm}$ year $^{-1}$, mostly as rain occurring mainly in four to seven rainy episodes during the winter season (IMS, 2011). 


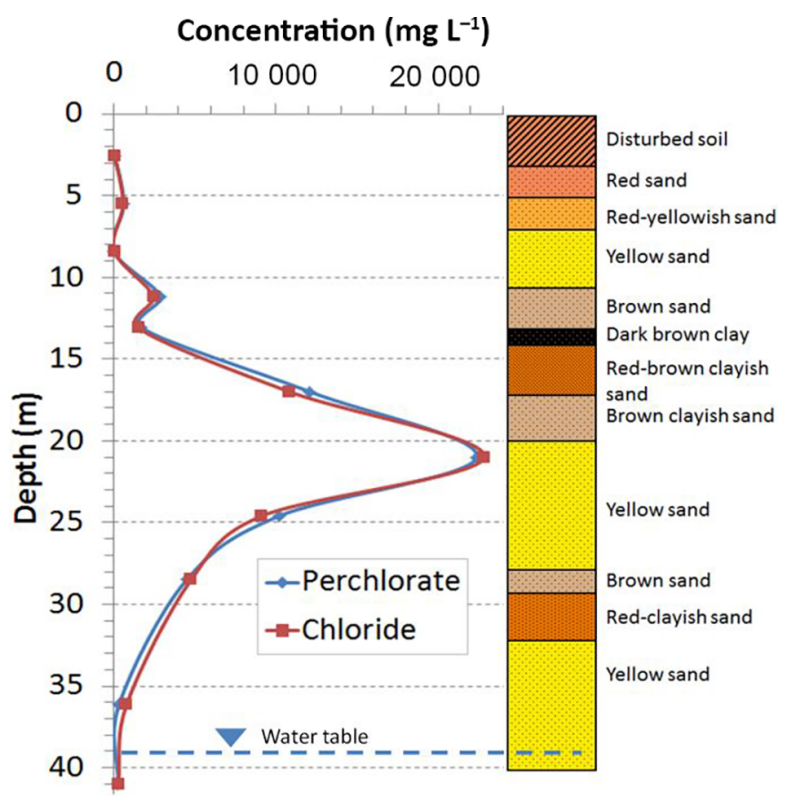

Figure 1. Initial concentration profiles of chloride and perchlorate in the vadose zone pore water under the former waste lagoon, along with the lithological profile.

Table 1. Sedimentological composition of the vadose zone at the pilot site.

\begin{tabular}{llr}
\hline Depth $(\mathrm{m})$ & Description & Clay content $(\%)$ \\
\hline $0-3$ & Red sand (disturbed) & 7.5 \\
$3-5$ & Red sand (Hamra) & 5 \\
$5-7$ & Red-yellowish sand & 5 \\
$7-10$ & Yellow sand & 5 \\
$10-13$ & Brown sand & 5 \\
$13-14$ & Dark brown clay & 27.5 \\
$14-17$ & Red-brown clayish sand & 12.5 \\
$17-20$ & Brown clayish sand & 3.75 \\
$20-27$ & Yellow sand & 1 \\
$28-29$ & Brown sand & 11.75 \\
$29-33$ & Red-clayish sand (Hamra) & 3 \\
$33-41$ & Yellow sand & 0 \\
\hline
\end{tabular}

\section{Experimental setup}

\subsection{Vadose zone monitoring setup}

Real-time characterization of flow and transport processes in the vadose zone, as well as assessment of chemical transformation of the percolating water during the remediation experiments, was carried out with a VMS that was installed across the entire unsaturated profile, from land surface to a depth of $37 \mathrm{~m}$ (Fig. 2). A detailed description of the VMS, its structure, installation procedure and performance can be found in previous publications (Dahan et al., 2009; Rimon et al., 2011a) and in the Supplement. In particular, the VMS that

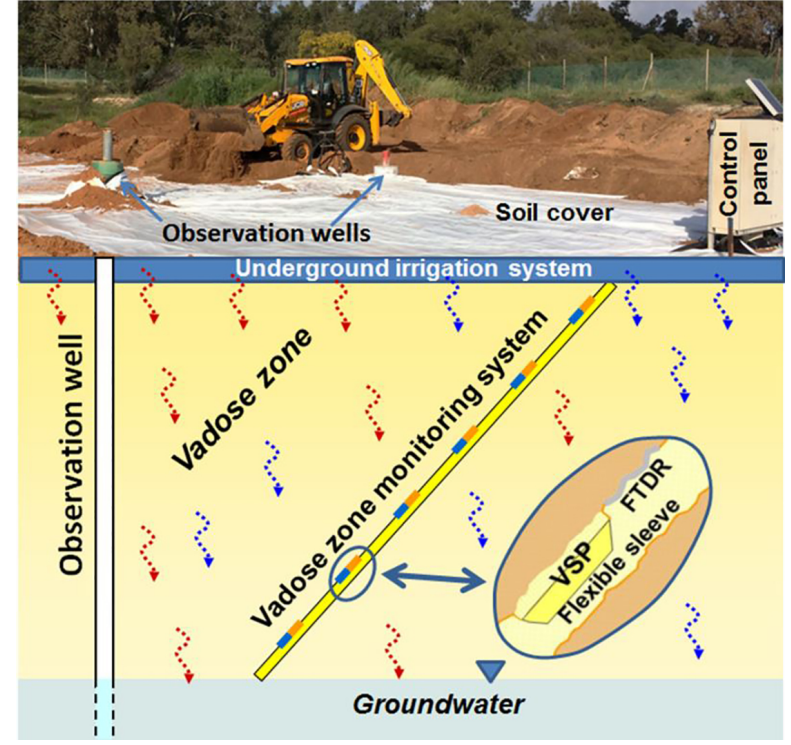

Figure 2. Schematic illustration of the vadose zone monitoring system installed in the vadose zone under the infiltration pilot site. In the picture above the vadose zone, the irrigation system at the site is being covered.

was used at this site was composed of a $44 \mathrm{~m}$ long flexible polyurethane sleeve hosting 11 monitoring units distributed along its length. Each monitoring unit included: (a) a flexible time-domain reflectometer (FTDR) sensor for continuous measurement of variations in the sediment water content (Dahan et al., 2008; Rimon et al., 2007), and (b) vadose zone sampling ports (VSPs), which enable frequent sampling of the vadose zone pore water for chemical analysis (Baram et al., 2012a; Dahan et al., 2009; Rimon et al., 2011b; Turkeltaub et al., 2016). The VMS flexible sleeve was installed in a $0.16 \mathrm{~m}$ diameter uncased borehole drilled slanted at a $55^{\circ}$ angle (to the horizon) to a vertical depth of $37 \mathrm{~m}$. In addition to the 11 monitoring units that were installed with the VMS, four additional monitoring units were installed directly in the soil at depths of 0.5 and $1.5 \mathrm{~m}$. It should be noted that the slanted installation is preferred to ensure that measurements carried out by each monitoring unit take place in separate undisturbed sediment columns. In addition, the flexibility of the monitoring sleeve and its filling with non-shrinking cement grout ensured complete sealing of the borehole void and prevention of cross-contamination through preferential flow in the borehole.

\subsection{Field setup}

Water amended with ethanol as the electron donor for perchlorate-reducing bacteria was infiltrated into the vadose zone through an area of $8 \times 30 \mathrm{~m}$ at the pilot site using a dripirrigation system. Dripping lines with drippers having a nominal discharge rate of $2.2 \mathrm{Lh}^{-1}$ were set up in a $0.3 \times 0.3 \mathrm{~m}$ spatial distribution to create fairly even water distribution 
Table 2. Infiltration experiment conditions.

\begin{tabular}{lrrrr}
\hline Date & $\begin{array}{r}\text { Water volume } \\
\left(\mathrm{m}^{3}\right)\end{array}$ & $\begin{array}{r}\text { Equivalent water } \\
\text { depth }(\mathrm{mm})\end{array}$ & $\begin{array}{r}\text { Ethanol } \\
(\mathrm{L})\end{array}$ & $\begin{array}{r}\text { Bromide } \\
(\mathrm{kg})\end{array}$ \\
\hline 8 August 2010 & 50 & 210 & 50 & 5 \\
1 September 2010 & 100 & 420 & 50 & - \\
27 February 2011 & 300 & 1250 & 200 & - \\
\hline
\end{tabular}

over the area. Accordingly, the total discharge rate of the irrigation system was set to $5 \mathrm{~m}^{3} \mathrm{~h}^{-1}$, which is equivalent to an infiltration rate of $0.02 \mathrm{~m} \mathrm{~h}^{-1}$. To promote anaerobic conditions in the unsaturated zone, a polyethylene liner covered with soil was placed over the dripper system after its installation. Ethanol was selected as the electron donor and carbon substrate because it is a natural, soluble compound that is commonly used by perchlorate-reducing bacteria (Bardiya and Bae, 2011). Moreover, it reduces potential increase in soil salinity associated with other common sources of electron donors such as acetate (Gal et al., 2008).

\subsection{Infiltration experiments}

Three infiltration experiments with variable amounts of water and ethanol were implemented at the pilot site over a period of 7 months. To trace the percolating water across the unsaturated zone, bromide (as $\mathrm{KBr}$ ) was added to the infiltrating water at the early stages of the experiment. The infiltration rates, as well as the concentrations and application sequence were assigned for each experiment with insight gained from the previous experiment (Table 2). Accordingly, information obtained by the VMS on depth propagation of the ethanol and tracer and variations in perchlorate and chloride concentrations across the unsaturated zone during and after each infiltration experiment were used to adjust the infiltration procedure in the following stage.

The first experiment (8 August 2010) consisted of infiltration of $50 \mathrm{~m}^{3}$ water (equivalent to $210 \mathrm{~mm}$ ) (Table 2). The first $6 \mathrm{~m}^{3}$ were applied as untraced fresh water with no ethanol to wet the topsoil. This wetting stage is essential to promoting deep transport and preventing accumulation of tracers and ethanol in the low-flow zone located on the margins of the dripper's influential zone. Following the initial wetting phase, $0.4 \mathrm{~m}^{3}$ of bromide tracer solution (as $\mathrm{KBr}$ ) at a concentration of $12.5 \mathrm{~g} \mathrm{~L}^{-1}$ was applied, followed by $1 \mathrm{~m}^{3}$ of water with $5 \%$ ethanol. Immediately after the application of the carbon and tracer solution, the rest of the water $\left(42.6 \mathrm{~m}^{3}\right)$ was applied to enhance transport of the ethanol and tracers to deeper parts of the vadose zone.

After obtaining the results pertaining to the wetting process, as well as tracer and ethanol migration in the vadose zone during the first infiltration experiment, a second experiment was performed (1 September 2010). This experiment was conducted with $100 \mathrm{~m}^{3}$ of water (equivalent to $420 \mathrm{~mm}$ ).
Here the first $7 \mathrm{~m}^{3}$ of water was injected into the topsoil as untraced fresh water, followed by $1 \mathrm{~m}^{3}$ of water with $5 \%$ ethanol, and then the rest of the water dose $\left(92 \mathrm{~m}^{3}\right)$. No tracers were used in this experiment. The amount of water used after application of the ethanol was doubled to enhance migration of the ethanol to deep sections of the unsaturated zone.

Results from the first two experiments indicated limited migration of tracer and ethanol to deeper parts of the vadose zone. A third infiltration experiment was therefore conducted 5 months later with increased discharge of $300 \mathrm{~m}^{3}$ (equivalent to $1250 \mathrm{~mm}$ ). This experiment started with $24 \mathrm{~m}^{3}$ of untraced water followed by $0.4 \mathrm{~m}^{3}$ concentrated $(50 \%)$ ethanol solution. Then, the rest of the water $\left(275.6 \mathrm{~m}^{3}\right)$ was used to push the ethanol down into the vadose zone. The large quantity of water applied after the concentrated ethanol solution was designed to enhance quick migration of the ethanol to deep parts of the vadose zone while minimizing its biodegradation in the upper soil layers.

\subsection{Analytical procedure}

Perchlorate was analysed with a perchlorate ion-selective electrode (ISE; Laboratory Perchlorate Ion Electrode, ColeParmer, USA). All samples measured with the ISE were adjusted by dilution to a concentration range of 10 $100 \mathrm{mg} \mathrm{L}^{-1}$. Duplicates were frequently analysed by injecting $25 \mu \mathrm{L}$ sample into a Thermo Scientific ${ }^{\mathrm{TM}}$ Dionex $^{\mathrm{TM}}$ ion chromatography system (ICS 5000) equipped with Ion Pac AS19 column (detection limit of $\pm 0.01 \mathrm{mg} \mathrm{L}^{-1}$ ). Because results from the two methods were not significantly different, most of the data reported here are from the perchlorate electrode with a detection limit of $1 \mathrm{ppm}$. Bromide and chloride were analysed by ion chromatography with a detection limit of $30 \mathrm{ppb}$ (Gal et al., 2008). Total organic carbon (TOC) was analysed to examine the success of delivering carbon to the vadose zone. Because porewater samples from the vadose zone are obtained through the VSP, which uses a porous ceramic interface (pore size $<2 \mu \mathrm{m}$ ), TOC values reflect DOC. TOC was analysed through a combustion TOC analyser (Teledyne Tekmar, Apollo 9000) with a detection limit of $2 \mathrm{ppm}$. Ethanol concentration in the vadose zone pore water was analysed in a gas chromatograph (Varian, CP3800). Water samples $(1.5 \mu \mathrm{L})$ were injected by autosampler. The flame ionization detector and injector temperatures 
were set to 270 and $250^{\circ} \mathrm{C}$, respectively. The GC oven temperature was first held at $50^{\circ} \mathrm{C}$ for $1 \mathrm{~min}$, increased to $220^{\circ} \mathrm{C}$ at a rate of $25^{\circ} \mathrm{C} \mathrm{min}^{-1}$, and then held for $4 \mathrm{~min}$. The separation was performed by Stabilwax ${ }^{\circledR}$ capillary column $(60 \mathrm{~m}$, $0.32 \mathrm{~mm}, 0.25 \mu \mathrm{m}$, Restek Corporation, USA); helium was used as the carrier gas $\left(1 \mathrm{~mL} \mathrm{~min}^{-1}\right)$. For quantification, five external standards were used.

\section{Results and discussion}

All of the data obtained by the VMS are presented here as variations in measured parameters with depth, as commonly done to describe depth profiles. However, to ensure measurements under undisturbed vertical profiles, the VMS was installed in a slanted orientation (Fig. 2 and Supplement). Thus, each monitoring unit faces an undisturbed profile that is shifted horizontally and vertically from the other units. Accordingly, although the data are presented as depth profiles, they should be regarded as individual points distributed across the 3-D space of the vadose zone (Dahan et al., 2007; Rimon et al., 2011a).

Prior to detailed discussion on the results, a general outline of the rationale behind the experimental setup will be presented here. Three infiltration experiments were conducted with variable amounts of water, ethanol as electron donor, and bromide as a tracer (see Sect. 3.3). Nevertheless, the experimental conditions in each experiment were set following the results obtained from the previous stage. The first infiltration experiment was conducted as a first trial to infiltrate ethanol-enriched water-solution into the unsaturated zone. This experiment was also conducted with bromide as a tracer in order to mark the water front propagation across the unsaturated zone. As will be discussed in what follows, results of the first infiltration experiment indicated that the migration capacity of both ethanol and bromide across the unsaturated profile was very limited. Accordingly a second infiltration experiment was conducted with a double amount of water and the same amount and concentration of ethanol in order to enhanced deep migration of the ethanol down the unsaturated zone. Following the results from the first two experiments a third infiltration experiment was conducted with larger water volumes and higher ethanol concentration in order to avoid quick ethanol degradation in the shallow soil. All of which will be presented and discussed below.

\subsection{Water percolation}

Temporal variations in the vadose zone water content provide a direct indication of percolation processes in the vadose zone (Rimon et al., 2007; Dahan et al., 2008; Turkeltaub et al., 2015a). Each infiltration experiment launched a wetting wave that propagated sequentially through the unsaturated zone (Fig. 3). Down-migration of the wetting wave was expressed as a quick rise in water content followed by a reces-

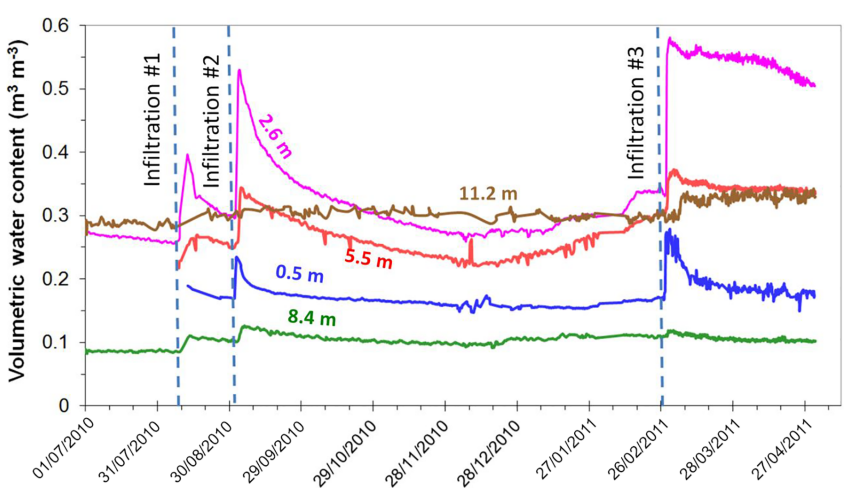

Figure 3. Temporal variations in sediment water content in the top $13 \mathrm{~m}$ of the vadose zone during the infiltration experiments. Dates are given as day/month/year.

sion caused by water redistribution and drainage. Referring the wetting sequence in the vadose zone to the infiltration events on land surface enabled a direct calculation of the flow velocity across the unsaturated zone (Rimon et al., 2007; Dahan et al., 2008). All three infiltration experiments produced wetting fronts that moved down the vadose zone at a velocity of $\sim 0.18 \mathrm{~m} \mathrm{~h}^{-1}$, even though the water volumes that were used in each experiment were significantly different $(50,100$ and $300 \mathrm{~m}^{3}$ ). Additional information on calculation procedure of flow velocities may be found in the Supplement. Observations of regulated flow velocities at constant rates across the vadose zone under variable surface hydraulic conditions have also been reported in other studies (Dahan et al., 2008; Amiaz et al., 2011; Rimon et al., 2011a).

The high salinity of the deeper parts of the vadose zone $(>13 \mathrm{~m}$ ) (Fig. 1) limits the reliability of the TDR technology for measuring water content at those depths (Nadler et al., 1999). Therefore, variation in water content, as an indication of deep percolation, is presented here only down to a depth of $11.2 \mathrm{~m}$, where the salinity was low enough to achieve reliable moisture measurements with the FTDR sensors. Nevertheless, indications of deep percolation in the deeper layers $(>13 \mathrm{~m})$ are further discussed through the variation in chemical composition of the percolating water across the entire thickness of the unsaturated zone $(40 \mathrm{~m})$.

\subsection{Perchlorate transformation and mobilization}

Initial analysis of pore-water samples from the vadose zone, prior to initiation of the infiltration experiments, revealed very high concentrations of perchlorate and chloride, both reaching maximum values of $\sim 22500 \mathrm{mg} \mathrm{L}^{-1}$ (Fig. 1), and total dissolved solids (TDS) of $43000 \mathrm{mg} \mathrm{L}^{-1}$, at a depth of $21 \mathrm{~m}$. Note that at this stage, the concentrations of perchlorate and chloride are nearly identical throughout the entire profile. These high concentrations, sampled by the VMS, are in accordance with concentration profiles obtained previously in extracts of sediment samples (Gal et al., 2009). 


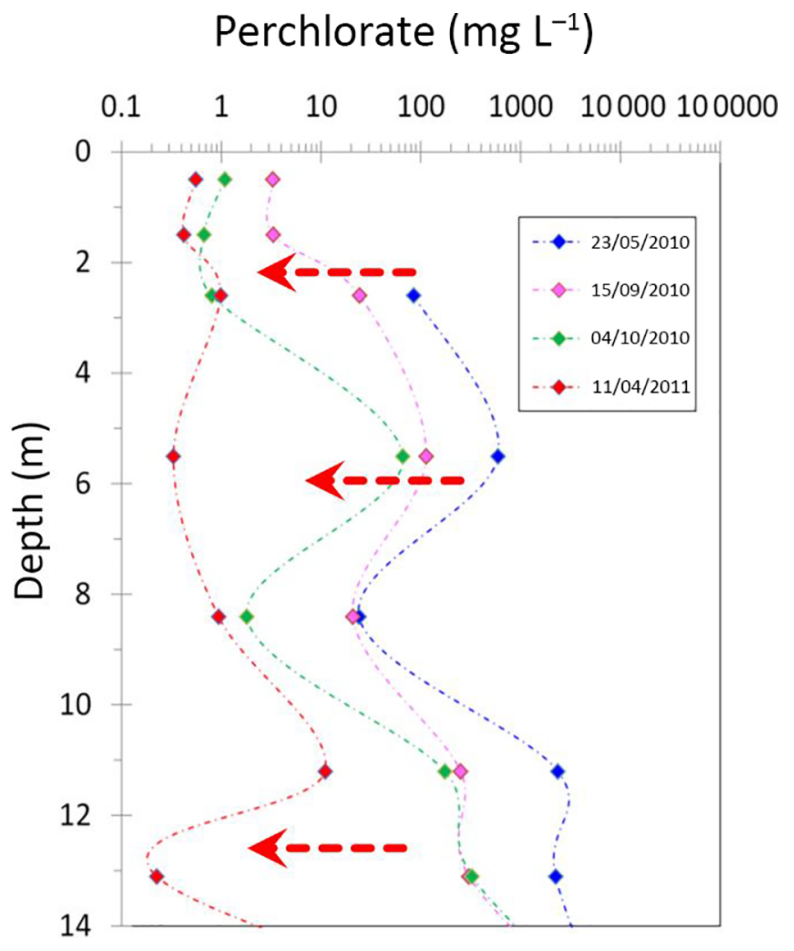

Figure 4. Perchlorate concentration profile across the top $13 \mathrm{~m}$ of the vadose zone under the pilot site during the infiltration experiments. The profiles emphasize the gradual decrease in perchlorate concentration with time (marked in red arrows). Dates are given as day/month/year. Note that data points are aligned in a slanted orientation and interpolated as time intervals.

Frequent sampling of the vadose zone pore water showed dynamic variations in perchlorate concentration during the percolation experiments. In the upper section of the vadose zone $(0-13 \mathrm{~m})$, perchlorate concentrations decreased dramatically, from as high as $9000 \mathrm{mg} \mathrm{L}^{-1}$ to below detection levels (Fig. 4). Such a reduction in concentration in a relatively thick portion of the vadose zone $(13 \mathrm{~m})$ over the short period of 10 months is clearly desirable and may even be considered a great success. Nevertheless, closer inspection of the variations in perchlorate concentration in deep parts of the vadose zone $(17-40 \mathrm{~m})$ showed an increase at most of the measurement points (Fig. 5). Perchlorate concentration rose from 12700 to $27400 \mathrm{mg} \mathrm{L}^{-1}$ at a depth of $17 \mathrm{~m}$ during the same period. A similar increase in concentration was also found in deeper parts of the cross section at depths of 25, 28, and $36 \mathrm{~m}$. Note that during this period, an increase in perchlorate concentration was even observed in the groundwater (represented at a depth of $41 \mathrm{~m}$ in Fig. 5). Obviously, the mixed trend in variations of perchlorate concentration implies that transformation and mobilization processes take place simultaneously. As such, the conditions for both biodegradation and mobilization should be examined along with the variation in perchlorate concentration.

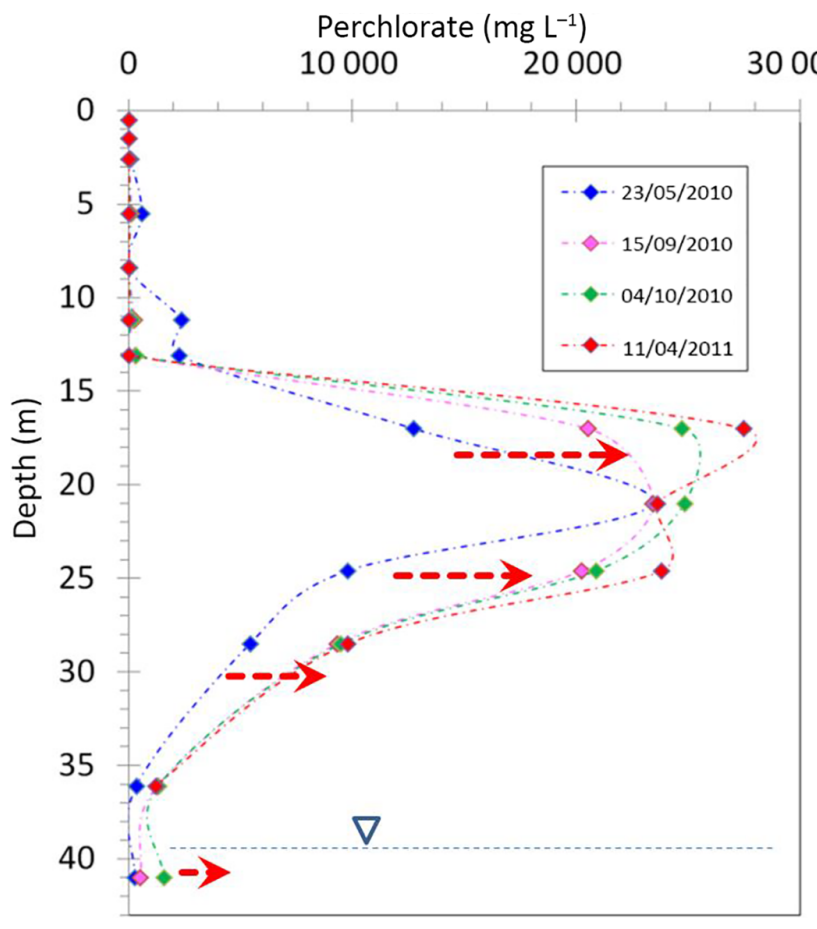

Figure 5. Perchlorate concentration profile across the entire vadose zone and top groundwater under the pilot site during the infiltration experiments. The profiles emphasize the gradual increase in perchlorate concentration with time (marked in red arrows). Dates are given as day/month/year. Note that data points are aligned in a slanted orientation and interpolated as time intervals.

\subsection{Electron donor availability}

Available organic carbon as an electron donor is crucial for perchlorate reduction. To increase the concentration of DOC in the vadose zone, ethanol was mixed with the percolating water during the early stage of each infiltration experiment. Analysis of ethanol and DOC in the water samples from the vadose zone throughout the experiment revealed high correlation between the two. Theoretically $1 \mathrm{~g}$ per litre of ethanol is equal $0.52 \mathrm{~g} \mathrm{~L}^{-1}$ of soluble carbon. However, in the site the dissolved carbon is composed of ethanol, its microbial metabolism products (such as acetate), and other soluble microbial metabolites that can also serve as electron donors. Thus, DOC provides a better knowledge on the availability of electron donors in the soil pore water. Accordingly, we assume that the variation in DOC during the experiments was due to transport of ethanol or ethanol-degradation products with the percolating water (for further details correlation between DOC and ethanol concentration see the Supplement).

During the first infiltration experiment, an increase in DOC above background levels was observed only at shallow depths, down to $1.5 \mathrm{~m}$ (Fig. 6). No signs of increasing DOC were observed in the deeper parts of the cross section at this stage. Twenty-three days later, before initiation of the second 


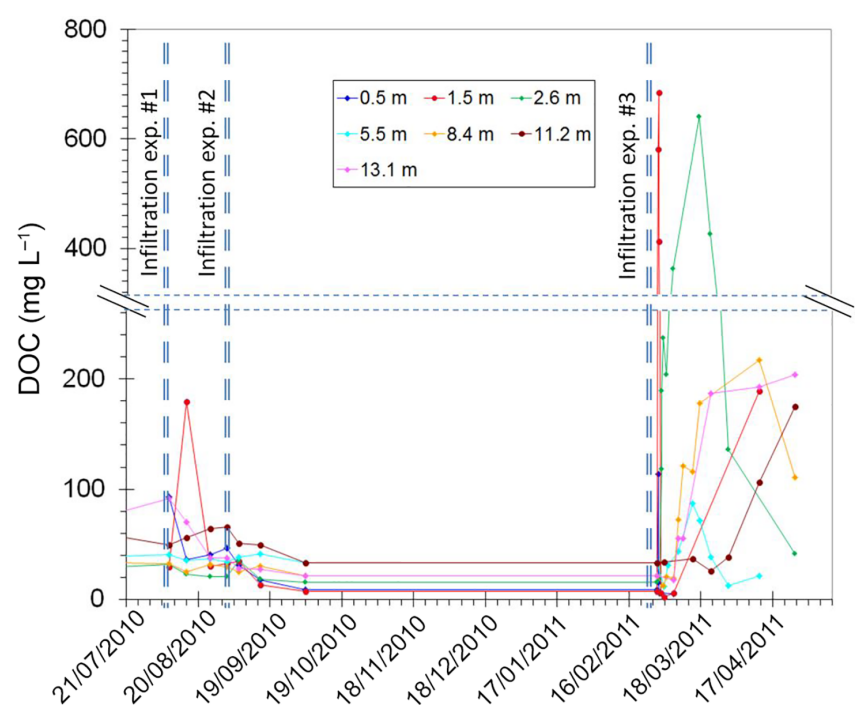

Figure 6. Variations in dissolved organic carbon (DOC) across the top $13 \mathrm{~m}$ of the vadose zone following infiltration of water enriched with ethanol. Dates are given as day/month/year.

infiltration experiment, DOC values had dropped back down to background levels. This implies that the ethanol was microbiologically consumed and mineralized to inorganic carbon in the soil before it could be leached further down.

As a result of the limited transport of electron donor, ethanol, in the first infiltration experiment, a second experiment was conducted with the same mass and concentration of ethanol. However, it was flushed with double the amount of water to promote its quicker migration to deeper layers (Fig. 4). In this experiment, no signs of increasing DOC were observed at any depth. However, DOC level decreased to values below background levels (Fig. 6). Obviously, the rate of ethanol metabolism and mineralization in the soil increased following the first experiment, where both water content of the sediment and substrate required for efficient microbial activity increased. As a result, ethanol-degradation efficiency in the topsoil $(<0.5 \mathrm{~m})$ was significantly enhanced.

To overcome the limitation of electron donor delivery through the shallow soils, a third infiltration experiment was designed. In this experiment, the ethanol was injected in a $0.4 \mathrm{~m}^{3}$ high-concentration $(50 \% \mathrm{vol})$ pulse followed by a large volume of water. Application of ethanol at a very high concentration was aimed at suppressing its biological degradation in the shallow soil. The ethanol pulse was introduced after application of $24 \mathrm{~m}^{3}$, the latter to provide high initial wetting conditions under the ethanol front. Then the ethanol slug was pushed down with $276 \mathrm{~m}^{3}$ of water. At this stage of the study, which was conducted 6 months after the previous one, a substantial increase in DOC was observed in the entire top $13 \mathrm{~m}$ of the cross section (Fig. 6). Obviously, an increase in DOC serving as electron donor is an essential prerequisite for perchlorate degradation. Apparently, application of

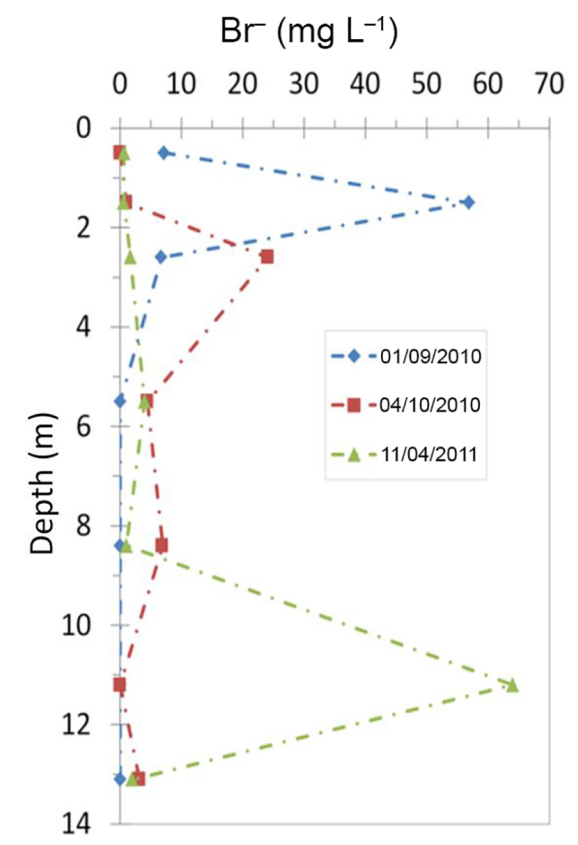

Figure 7. Variations in bromide concentration profile across the top $13 \mathrm{~m}$ of the vadose zone during the infiltration experiments. Dates are given as day/month/year. Note that data points are aligned in a slanted orientation and interpolated as time intervals.

ethanol at a high concentration, which inhibited its degradation in the upper layer, succeeded to drive the ethanol all the way down to $13 \mathrm{~m}$, just above the clay layer. Nevertheless, no signs of DOC increase were observed below $13 \mathrm{~m}$.

\subsection{Transport and degradation}

The mechanism controlling down-propagation of a nonconservative substance such as ethanol may be elucidated by looking at the migration pattern of a conservative tracer such as bromide. Bromide was injected with the percolating water in the early stages of the first infiltration experiment. Results on bromide migration are presented here only for the top $13 \mathrm{~m}$, where the background concentrations prior to the initiation of the infiltration experiment were below detection limits. Concentration profiles during the infiltration experiments clearly demonstrated sequential progress of the percolating water across the top $13 \mathrm{~m}$ of the unsaturated zone (Fig. 7). Mass balance calculation of bromide on the basis of the concentration profiles (Fig. 7) and sediment water content (Fig. 3) on various dates after the infiltration experiment resulted in high recovery rates of $85-127 \%$. A comparison of the transport patterns of bromide and DOC confirmed that biodegradable material such as ethanol is rapidly consumed in the vadose zone.

An increase in chloride concentration in the vadose zone is usually attributed to evaporation processes near land surface, a mechanism that is unlikely to occur in this particular setup where the surface is isolated from the atmosphere. Accord- 


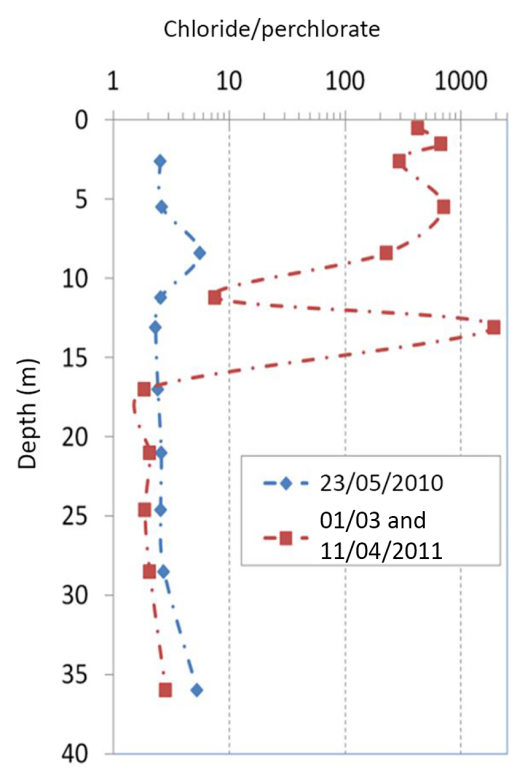

Figure 8. Chloride-to-perchlorate equivalent concentration ratio profiles before and after the infiltration experiments. Dates are given as day/month/year. Note that data points are aligned in a slanted orientation and interpolated as time intervals.

ingly, variations in chloride concentration across the vadose zone may be attributed to chloride mobilization with the percolating water and perchlorate reduction. Therefore, degradation of perchlorate is expected to result in an increase in chloride mass.

Prior to the infiltration experiments, chloride-toperchlorate ratios in the vadose zone were very similar, exhibiting nearly identical profiles (Fig. 1) with equivalent concentration proportions of 2.4-5.5 (Fig. 8). Following the infiltration experiment, a significant increase in ionic ratios was observed in the top $13 \mathrm{~m}$, while in the rest of the profile - from a depth of $17 \mathrm{~m}$ to the water table the concentration ratio of chloride to perchlorate remained relatively unchanged. Obviously, since both perchlorate and chloride are very soluble and mobile, infiltration water with a low concentration of chloride $\left(\sim 100 \mathrm{mg} \mathrm{L}^{-1}\right)$ and zero perchlorate is also expected to result in an increased chloride-to-perchlorate ratio, even if no perchlorate degradation takes place. Since both chloride and perchlorate are very mobile and easily displaced with the percolating water, quantification of the perchlorate-degradation rate with respect to its down-leaching is not straightforward.

\section{Conclusions}

The infiltration experiments were primarily aimed at improving the environmental conditions for perchlorate-reducing bacteria across the vadose zone. This included an increase in water content along the soil profile and amendment of the electron donor. The results, which were based on continu- ous monitoring of the entire vadose zone, exhibited notable variation in the concentrations of perchlorate, DOC and other solutes in the unsaturated zone. Increased concentrations of DOC with a concurrent reduction in perchlorate concentration (from thousands to a few milligrams per litre) and increased chloride-to-perchlorate ratio (from $\sim 2.5$ to $\sim 300$ ) in the upper $13 \mathrm{~m}$ indicated that perchlorate is partially reduced in this part of the vadose zone. On the other hand, no evidence of improved reducing conditions was observed in the deeper parts, where the initial concentrations of perchlorate were significantly higher. Nevertheless, since assessment of redox conditions in deep vadose zone is not yet feasible, we can only rely on variations in the chemical composition to assess the existence of degradative conditions.

The limited ability to deliver a soluble electron donor across a microbiologically reactive medium, such as topsoil, is a major limiting factor for remediation of the deep vadose zone through gravitational percolation of enriched solution. Note that temporal variations in the concentrations of perchlorate, as well as other solutes, in the deep parts of the vadose zone, i.e. under the clay layer at $14 \mathrm{~m}$, indicate that the clay layer does not play any role in limiting infiltration capacity in terms of flow velocity and fluxes. Similar observations on the role of clay layers in infiltration in the unsaturated zone have been reported in previous publications (Baram et al., 2012b, c; Dahan et al., 2009; Rimon et al., 2007; Turkeltaub et al., 2015b).

The attempts to leach the ethanol down into the vadose zone with large quantities of water inevitably drove downleaching and displacement of the dissolved solutes, including perchlorate. Although there were indications of partial degradation of perchlorate in the upper part of the vadose zone, its downward displacement toward the water table was evident from the sequential increase in perchlorate concentration with depth (Fig. 5). It seems that the entire column of perchlorate mass was pushed down by the percolating water toward the water table, which also resulted in an increased concentration of perchlorate in the observation well, which was located under the infiltration zone.

Enhancing biodegradation of contaminants in the vadose zone while minimizing their down-migration into groundwater is a major challenge in remediation operations that involve water infiltration. Although in this study we have observed dramatic reduction in perchlorate concentration in the top $13 \mathrm{~m}$ of the unsaturated zone following the infiltration of ethanol enriched water solution, we cannot state that the reduction in perchlorate concentration is only due to bio-degradation and exclude partial down leached to deeper parts of the vadose zone. Accordingly, perchlorate degradation versus migration process were investigated through the temporal variation in perchlorate concentration with respect to variations in concentrations of ethanol, which was consumed in the subsurface, $\mathrm{Br}$, which is conservative tracer, and variations in the chloride concentration, which is a perchlo- 
rate final degradation product. All of which provided indicator hints to the question on the degradation versus leaching.

The study demonstrates that application of vadose zone monitoring technology during a remediation operation provides real-time information on the chemical and hydrological state of the subsurface. Linking the temporal variation in the chemical composition of the vadose zone pore water, sediment saturation degree and flow velocities is vital for efficient management of remediation operations.

Data availability. All required information and appropriate references appear in the Supplement.

\section{The Supplement related to this article is available online at https://doi.org/10.5194/hess-21-4011-2017- supplement.}

Author contributions. OD (PI, vadose zone hydrology) designed the experimental and monitoring setup. IK (MSc student) conducted the field experiment and laboratory analysis. LA (MSc student) conducted data analysis and modelling of flow and transport in the unsaturated zone. ZR (PI, microbiology) design the bio-treatment setup. Data analysis and paper preparation involved all coauthors.

Competing interests. The authors declare that they have no conflict of interest.

Acknowledgements. The authors wish to express their appreciation to the Israeli Water Authority for project funding.

Edited by: Erwin Zehe

Reviewed by: Marnik Vanclooster and one anonymous referee

\section{References}

Allaire, S. E., Roulier, S., and Cessna, A. J.: Quantifying preferential flow in soils: A review of different techniques, J. Hydrol., 378, 179-204, https://doi.org/10.1016/j.jhydrol.2009.08.013, 2009.

Amiaz, Y., Sorek, S., Enzel, Y., and Dahan, O.: Solute transport in the vadose zone and groundwater during flash floods, 47, 1-10, https://doi.org/10.1029/2011WR010747, 2011.

Attaway, H. and Smith, M.: Reduction of perchlorate by an anaerobic enrichment culture, J. Ind. Microbiol., 12, 408-412, https://doi.org/10.1007/BF01569673, 1993.

Baram, S., Arnon, S., Ronen, Z., Kurtzman, D., and Dahan, O.: Infiltration Mechanism Controls Nitrification and Denitrification Processes under Dairy Waste Lagoon, J. Environ. Qual., 41, 1623-1632, https://doi.org/10.2134/jeq2012.0015, 2012a.

Baram, S., Arnon, S., Ronen, Z., Kurtzman, D., and Dahan, O.: Infiltration Mechanism Controls Nitrification and Denitrification
Processes under Dairy Waste Lagoon, J. Environ. Qual., 41, 1623-1632, https://doi.org/10.2134/jeq2012.0015, 2012b.

Baram, S., Kurtzman, D., and Dahan, O.: Water percolation through a clayey vadose zone, J. Hydrol., 424-425, 165-171, https://doi.org/10.1016/j.jhydrol.2011.12.040, 2012c.

Bardiya, N. and Bae, J.-H.: Dissimilatory perchlorate reduction: A review, Microbiol. Res., 166, 237-254, 2011.

Battey, T. F., Shepard, A. J., and Tait, R. J.: Soil Flushing Through a Thick Vadose Zone Perchlorate Removal Documented at Edw, in: AGU, American Geophysical Union, Fall Meeting 2007, abstract \#H33E-1685, 10-14 December 2007.

Bautersa, T. W. J., DiCarlob, D. A., Steenhuisa, T. S., and Parlangea, J.-Y.: Soil water content dependent wetting front characteristics in sands, J. Hydrol., 231-232, 244-254, 2000.

Bombach, P., Richnow, H. H., Kästner, M., and Fischer, A.: Current approaches for the assessment of in situ biodegradation, Appl. Microbiol. Biotechnol., 86, 839-852, 2010.

Cai, H., Eramo, A. G. A. G., Evans, P. J. P. J., Fricke, R., and Brennan, R. A. R. A.: In Situ Bioremediation of Perchlorate in Vadose Zone Soil Using Gaseous Electron Donors: Microcosm Treatability Study, Water Environ. Res., 82, 409-417, https://doi.org/10.2175/106143009X12487095237198, 2010.

Coates, J. D. and Achenbach, L. A.: Microbial perchlorate reduction: rocket-fueled metabolism, Nat. Rev. Microbiol., 2, 569580, https://doi.org/10.1038/nrmicro926, 2004.

Dahan, O., Shani, Y., Enzel, Y., Yechieli, Y., and Yakirevich, A.: Direct measurements of floodwater infiltration into shallow alluvial aquifers, J. Hydrol., 344, 157-170, 2007.

Dahan, O., Tatarsky, B., Enzel, Y., Kulls, C., Seely, M., and Benito, G.: Dynamics of flood water infiltration and ground water recharge in hyperarid desert, Ground Water, 46, 450-461, https://doi.org/10.1111/j.1745-6584.2007.00414.x, 2008.

Dahan, O., Talby, R., Yechieli, Y., Adar, E., Lazarovitch, N., and Enzel, Y.: In Situ Monitoring of Water Percolation and Solute Transport Using a Vadose Zone Monitoring System, Vadose Zo. J., 8, 916-925, 2009.

Dahan, O., Babad, A., Lazarovitch, N., Russak, E. E., and Kurtzman, D.: Nitrate leaching from intensive organic farms to groundwater, Hydrol. Earth Syst. Sci., 18, 333-341, https://doi.org/10.5194/hess-18-333-2014, 2014.

DiCarlo, D. A.: Capillary pressure overshoot as a function of imbibition flux and initial water content, Water Resour. Res., 43, W08402, https://doi.org/10.1029/2006WR005550, 2007.

EPA: How to Evaluate Alternative Cleanup Technologies for Underground Storage Tank Sites: A Guide for Corrective Action Plan, available at: www.epa.gov/oust/pubs/tums.htm (last access: July 2016), 2004.

EPA: Remediation Technologies-Tools and resources to assist in contaminated site remediation, available at: http://www.epa.gov/ superfund/remedytech/remed.htm (last access: July 2016), 2015.

Evans, P. J. and Trute, M. M.: In Situ Bioremediation of Nitrate and Perchlorate in Vadose Zone Soil for Groundwater Protection Using Gaseous Electron Donor Injection Technology, Water Environ. Res., 78, 2436-2446, https://doi.org/10.2175/106143006X123076, 2006.

Evans, P. J., Fricke, R. A., Hopfensperger, K., and Titus, T.: In Situ Destruction of Perchlorate and Nitrate Using Gaseous Electron Donor Injection Technology, 4, 103-112, https://doi.org/10.1111/j.1745-6592.2011.01355.x, 2011. 
Flury, M. and Wai, N.: Dyes as Tracers for Vadose Zone Hydrology, Rev. if Geophys., 41, 1-37, 2003.

Frankel, A. and Owsianiak, L.: In-situ anaerobic remediation of perchlorate-impacted soils, available at: http://www. environmental-expert.com (last access: 13 November 2014), 2005.

Gal, H., Ronen, Z., Weisbrod, N., Dahan, O., and Nativ, R.: Perchlorate biodegradation in contaminated soils and the deep unsaturated zone, Soil Biol. Biochem., 40, 1751-1757, https://doi.org/10.1016/j.soilbio.2008.02.015, 2008

Gal, H., Weisbrod, N., Dahan, O., Ronen, Z., and Nativ, R.: Perchlorate accumulation and migration in the deep vadose zone in a semiarid region, J. Hydrol., 378, 142-149, https://doi.org/10.1016/j.jhydrol.2009.09.018, 2009.

Germann, P. F. and al Hagrey, S. A.: Gravity-Driven and ViscosityDominated Infiltration into a Full-Scale Sand Model, Vadose Zo. J., 7, 1160, https://doi.org/10.2136/vzj2007.0172, 2008.

Gvirtzmen, M.: Israel Water Resources: Chapters in Hydrology and Envirmental Sciences, Yad Ben-Zvi Press, Jerusalem, 301 pp., 2002 (in Hebrew).

Hallett, P. D., Karim, K. H., Glyn Bengough, A., and Otten, W.: Biophysics of the Vadose Zone: From Reality to Model Systems and Back Again, Vadose Zo. J., 12, https://doi.org/10.2136/vzj2013.05.0090, 2013.

Höhener, P. and Ponsin, V.: In situ vadose zone bioremediation, Curr. Opin. Biotechnol., 27, 1-7, 2014.

IMS: Israel Meteorological Service, official Climate Data Base, available at: http://www.ims.gov.il/IMSEng/CLIMATE (last access: 27 July 2017), 2011.

Jarvis, N. J.: A review of non-equilibrium water flow and solute transport in soil macropores: Principles, controlling factors and consequences for water quality, Eur. J. Soil Sci., 58, 523-546, https://doi.org/10.1111/j.1365-2389.2007.00915.x, 2007.

Kurtzman, D., Baram, S., and Dahan, O.: Soil-aquifer phenomena affecting groundwater under vertisols: a review, Hydrol. Earth Syst. Sci., 20, 1-12, https://doi.org/10.5194/hess-20-12016, 2016.

Megharaj, M., Ramakrishnan, B., Venkateswarlu, K., Sethunathan, N., and Naidu, R.: Bioremediation approaches for organic pollutants: a critical perspective, Environ. Int., 37, 1362-1375, https://doi.org/10.1016/j.envint.2011.06.003, 2011.

Motzer, W.: Perchlorate: Problems, Detection, and Solutions, Environ. Forensics, 2, 301-311, 2001.

Nadler, A., Gamliel, A., and Peretz, I.: Practical aspects of salinity effect on TDR-measured water content: A field study, SOIL Sci. Soc. Am. J., 63, 1070-1076, 1999.

Nozawa-Inoue, M., Scow, K. M., and Rolston, D. E.: Reduction of perchlorate and nitrate by microbial communities in vadose soil, Appl. Environ. Microbiol., 71, 3928-3934, https://doi.org/10.1128/AEM.71.7.3928-3934.2005, 2005.

Rimon, Y., Dahan, O., Nativ, R., and Geyer, S.: Water percolation through the deep vadose zone and groundwater recharge: Preliminary results based on a new vadose zone monitoring system, Water Resour. Res., 43, 1-12, https://doi.org/10.1029/2006WR004855, 2007.

Rimon, Y., Nativ, R., and Dahan, O.: Physical and Chemical Evidence for Pore-Scale Dual-Domain Flow in the Vadose Zone, Vadose Zo. J., 10, 322, https://doi.org/10.2136/vzj2009.0113, 2011a.
Rimon, Y., Nativ, R., and Dahan, O.: Vadose Zone Water Pressure Variation during Infiltration Events, Vadose Zo. J., 10, 1105, https://doi.org/10.2136/vzj2010.0061, 2011b.

Roote, S. D.: First Edition Ground-Water Remediation Technologies Analysis Technology Status Report?: Perchlorate Treatment Technologies, 1st Edn., Pittsburgh, PA, 2001.

Sagi-Ben Moshe, S., Dahan, O., Weisbrod, N., Bernstein, A., Adar, E., and Ronen, Z.: Biodegradation of explosives mixture in soil under different water-content conditions, J. Hazard. Mater., 203204, 333-340, https://doi.org/10.1016/j.jhazmat.2011.12.029, 2012.

Sher, Y., Baram, S., Dahan, O., Ronen, Z., and Nejidat, A.: Ammonia transformations and abundance of ammonia oxidizers in a clay soil underlying a manure pond, FEMS Microbiol. Ecol., 81, 145-155, 2012.

Shrout, J. D. and Parkin, G. F.: Influence of electron donor, oxygen, and redox potential on bacterial perchlorate degradation, Water Res., 40, 1191-1199, 2006.

Singer, A.: The Soils of Israel, Springer Verlag, Berlin, Germany, 2007.

Stumpp, C., Maloszewski, P., Stichler, W., and Fank, J.: Environmental isotope $(\delta 180)$ and hydrological data to assess water flow in unsaturated soils planted with different crops: Case study lysimeter station "Wagna” (Austria), J. Hydrol., 369, 198-208, https://doi.org/10.1016/j.jhydrol.2009.02.047, 2009.

Stumpp, C., Stichler, W., Kandolf, M., and Šimůnek, J.: Effects of Land Cover and Fertilization Method on Water Flow and Solute Transport in Five Lysimeters: A LongTerm Study Using Stable Water Isotopes, Vadose Zo. J., 11, https://doi.org/10.2136/vzj2011.0075, 2012.

Tipton, D. K., Rolston, D. E., and Scow, K. M.: Transport and biodegradation of perchlorate in soils, J. Environ. Qual., 32, 4046, 2003.

Trumpolt, C. W., Crain, M., Cullison, G. D., Flanagan, S. J. P., Siegel, L., and Lathrop, S.: Perchlorate: Sources, uses, and occurrences in the environment, Remediat. J., 16, 65-89, https://doi.org/10.1002/rem.20071, 2005.

Turkeltaub, T., Dahan, O., and Kurtzman, D.: Investigation of Groundwater Recharge under Agricultural Fields Using Transient Deep Vadose Zone Data, Vadose Zo. J., 13 https://doi.org/10.2136/vzj2013.10.0176, 2014.

Turkeltaub, T., Kurtzman, D., Bel, G., and Dahan, O.: Examination of groundwater recharge with a calibrated/validated flow model of the deep vadose zone, J. Hydrol., 522, 618-627, https://doi.org/10.1016/j.jhydrol.2015.01.026, 2015a.

Turkeltaub, T., Kurtzman, D., Russak, E., and Dahan, O.: Water Resources Research, Water Resour Res., 32, 4840-4847, https://doi.org/10.1002/2015WR017273, 2015b.

Turkeltaub, T., Kurtzman, D., and Dahan, O.: Real-time monitoring of nitrate transport in the deep vadose zone under a crop field - implications for groundwater protection, Hydrol. Earth Syst. Sci., 20, 3099-3108, https://doi.org/10.5194/hess-20-3099-2016, 2016.

Urbansky, E. T.: Perchlorate as an environmental contaminant, Environ. Sci. Pollut. Res., 9, 187-192, https://doi.org/10.1007/BF02987487, 2002.

Urbansky, E. T. and Brown, S. K.: Perchlorate retention and mobility in soils, J. Environ. Monitor., 5, 455-462, https://doi.org/10.1039/b301125a, 2003. 